\title{
USING THE PAPATHOMA TSUNAMI VULNERABILITY ASSESSMENT MODEL TO FORECAST PROBABLE IMPACTS, AND PLANNING IMPLICATIONS, OF A 500-YEAR TSUNAMI IN CAYUCOS, CALIFORNIA
}

\author{
A Thesis \\ presented to \\ the Faculty of California Polytechnic State University, \\ San Luis Obispo \\ In Partial Fulfillment \\ of the Requirements for the Degree \\ Master of City and Regional Planning in Architecture and Environmental Design \\ by \\ Andrew Robert Marshall \\ June 2015
}


(C) 2015

Andrew Robert Marshall

ALL RIGHTS RESERVED 


\section{COMMITTEE MEMBERSHIP}

TITLE: $\quad$ Using the Papathoma Tsunami Vulnerability Assessment Model to Forecast Probable Impacts, and Planning Implications, of a 500-year Tsunami in Cayucos, California

AUTHOR: $\quad$ Andrew Robert Marshall

DATE SUBMITTED: June 2015

COMMITTEE CHAIR: W. David Conn, Ph.D.

Professor of City \& Regional Planning

COMMITTEE MEMBER: Ken Topping, MS.

Associate Professor of City \& Regional Planning

COMMITTEE MEMBER: William Siembieda, Ph.D.

Professor of City \& Regional Planning 


\author{
ABSTRACT \\ Using the Papathoma Tsunami Vulnerability Assessment Model \\ To Forecast Probable Impacts, and Planning Implications, of a \\ 500-year Tsunami in Cayucos, California \\ Andrew Robert Marshall
}

This report focuses on using the Papathoma Tsunami Vulnerability Assessment Model (PTVA) to demonstrate the vulnerability of Cayucos to a 500-year tsunami, and uses the results to inform specific planning recommendations. By modeling inundation with GIS and analyzing building attributes via the PTVA model, this study has gone beyond any previous vulnerability assessments of Cayucos. Findings include:

delineation of the most vulnerable areas, estimates of numbers of lost civic buildings, commercial buildings and houses, as well as estimates of people displaced from tsunami damaged homes. The report goes on to discuss what mitigation measures are in place and what further specific steps could be taken to ensure the long term sustainability of the town and help reduce future tsunami losses.

In the absence of fully developed, and accessible assessment tools; local planners have had only basic information to assess the community's tsunami vulnerability. The Papathoma Tsunami Vulnerability Assessment Model (PTVA) is a validated method that uses available tsunami runup estimations and field data collection to produce a detailed assessment of individual building survivability and overall community vulnerability. 


\section{TABLE OF CONTENTS}

Page

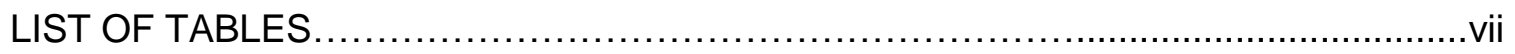

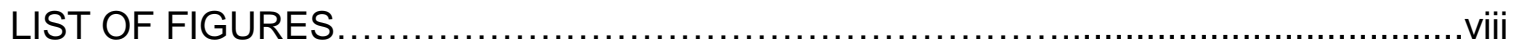

CHAPTER

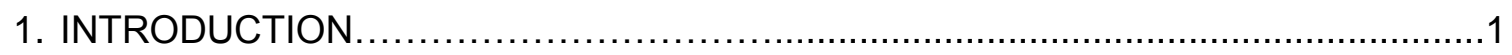

The San Luis Obispo County Local Hazard Mitigation Plan........................................6

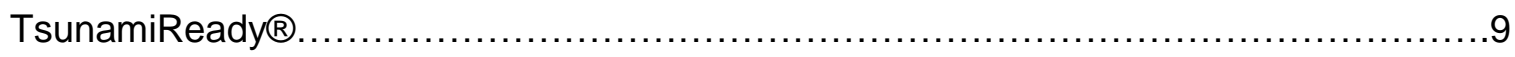

Tsunami Emergency Response Plan .....................................................

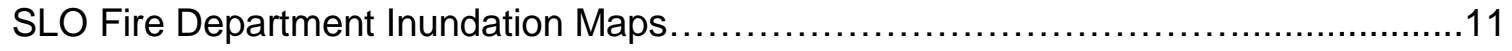

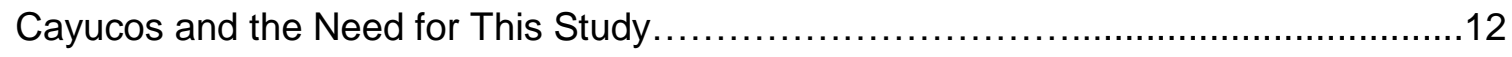

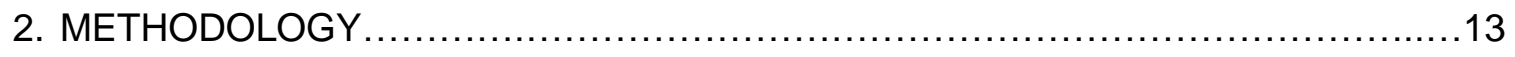

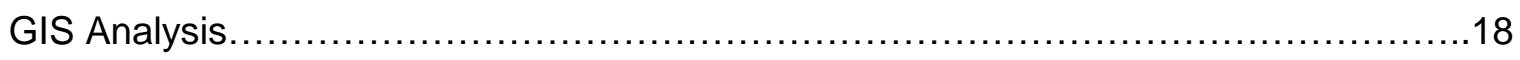

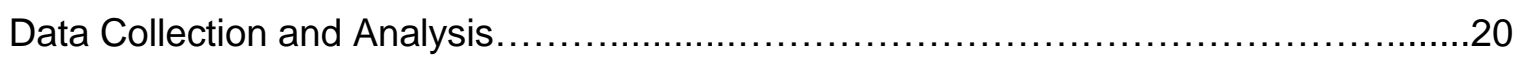

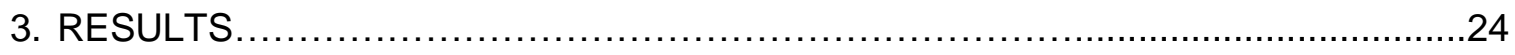

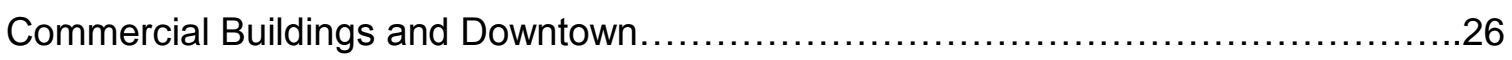

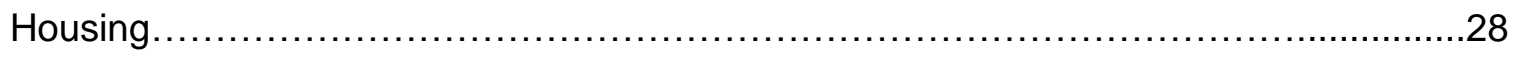

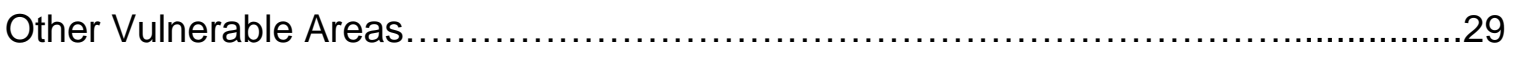

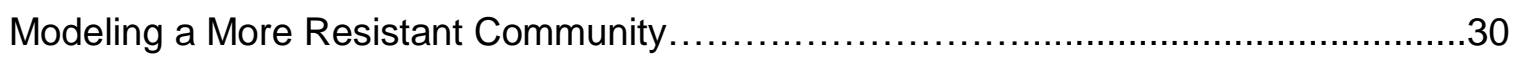

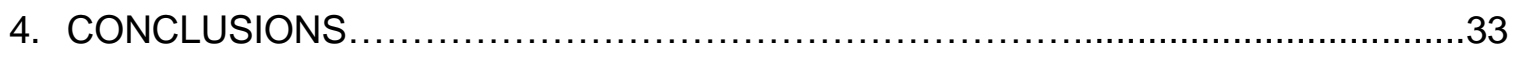




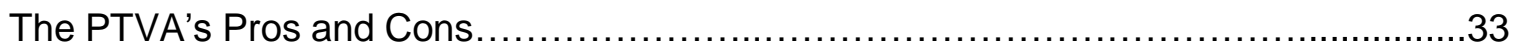

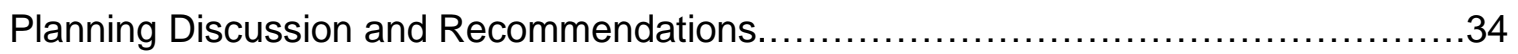

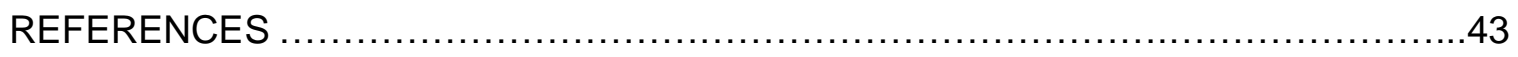

APPENDICES

Appendix A. SLO Fire Department, Northern Cayucos Inundation Map...................45

Appendix B. NWS/NOAA TsunamiReady® Guidelines.....................................46

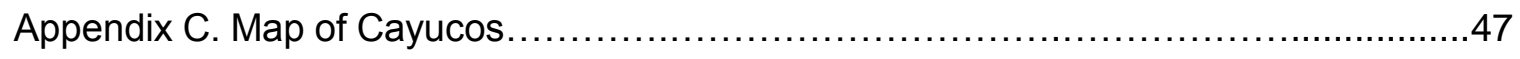

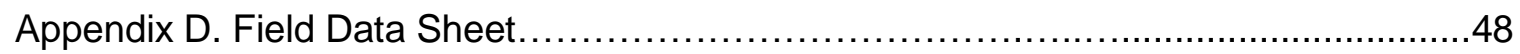




\section{LIST OF TABLES}

TABLE

Page

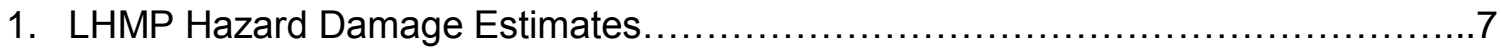

2. PTVA Attributes in Descending Order of Weighted Importance.............................17

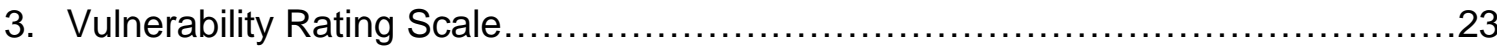




\section{LIST OF FIGURES}

Figure

Page

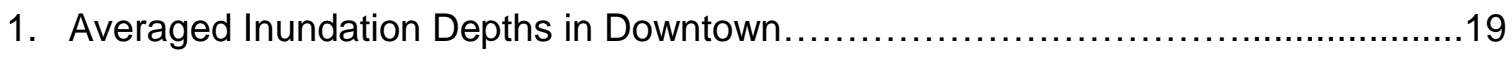

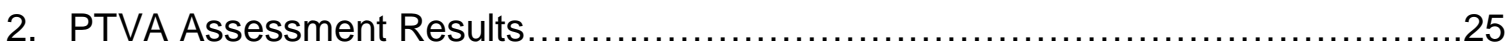

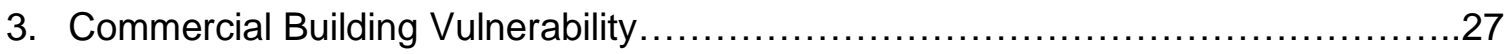

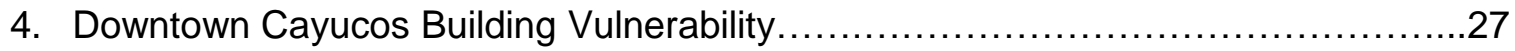

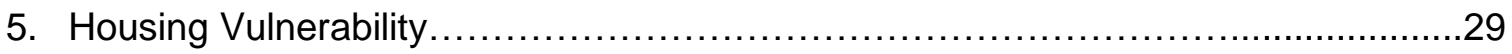

6. Revised Vulnerability Ratings for a Theoretically More Durable Cayucos.............32

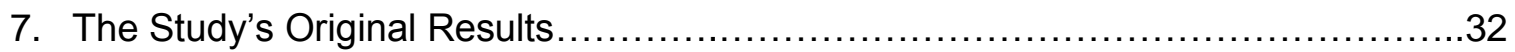




\section{Introduction}

Tsunamis are among the most devastating natural hazards and can affect almost any coast in the world. The Pacific Rim, known as the "Ring of Fire" to geologists, is a very seismically active region where tectonic plates that form the seafloor collide with the continents. The subduction zones that form at the tectonic plates' boundaries are capable of producing earthquakes that generate tsunamis that can radiate across the whole Pacific.

Tsunami waves have an extremely long wavelength and little height as they travel through the open ocean. They can cross an ocean at up to 600 miles per hour while causing little surface disturbance (CA OES, 2013). Upon entering shallow water a tsunami, like any wave, "feels bottom", its wavelength decreases and height increases. The resulting wave rushes onshore, often more like a rapidly rising tide than a curling, breaking wave. Most tsunami events consist of multiple waves. While the waves themselves are destructive, wave driven debris can cause much of the damage to the built environment. The severity of a tsunami is not measured by the height of the wave, but rather by the level of runup. Runup is the highest elevation on shore that the tsunami waves attain. The term inundation area is used to describe the inland area that is flooded. The inundation area is determined by local topography and runup height. Depending on these factors tsunami inundation may extend many kilometers inland, or only impact a narrow coastal margin.

The west coast of the United States is vulnerable to Pacific wide tsunamis caused by distant earthquakes, as well as locally generated tsunamis. There have been a total of 419 recorded tsunami events in the history of the U.S.A. (National Geophysical Data Center n.d.). The majority of these (308) have originated in the Pacific Ocean (National Geophysical Data Center n.d.). 
The areas of the world that are most likely to produce Pacific wide tsunamis (teletsunamis) are well known. Those most threatening to California include the Cascadia Subduction Zone off the Oregon coast, and the Aleutian Islands Subduction Zone (Miller, 2014). Tele-tsunamis can be very destructive but with modern technology their generation and arrival can be accurately predicted, and often there is time to evacuate and prepare. For example, a tsunami produced by the Cascadia Subduction Zone would arrive in California one to two hours after generation, while a tsunami from the Aleutian Islands would arrive in four to six hours (Miller, 2014).

The California coast could also be affected by tsunamis generated by local earthquakes or underwater landslides. These types of tsunamis can be just as destructive as or even more so than tele-tsunamis. The largest tsunami recorded in California was locally generated by an earthquake in the Santa Barbara Channel in 1812. It caused runup of 35 feet in Santa Barbara and 50 feet in Gaviota (SLO County, 2011). As locally generated tsunamis strike very shortly after their generating event, there is often little or no advance warning of their approach. A local tsunami could be onshore in as little as ten minutes after its generating event (Miller, 2014).

California has experienced many recorded tsunamis. However compared to other locations on the Pacific Rim, historical events in California have been mild. The one notable exception would be events in the northern Californian town of Crescent City, which has had about 30 tsunamis in the last 80 years and has suffered the loss of dozens of lives (Padilla, 2012).

San Luis Obispo County, on the central coast of California, has also experienced tsunamis, but nothing that could be considered a major event. The County is vulnerable to tele-tsunamis (those generated over 1000 miles away) as well as tsunamis that could be generated by local faults (SLO County, 2013). It has been affected by all of the 
notable Pacific wide tele-tsunamis of the last century, including the 2011 Tohoku tsunami, which caused $\$ 500,000$ in damage to docks and piers in Morro Bay (SLO County, 2013). Typically, tsunami runups experienced in San Luis Obispo have not exceeded more than a few meters above sea level, and caused only limited damage and no recorded loss of life (SLO County, 2013).

Coastal areas in San Luis Obispo County are also vulnerable to sea level rise that can magnify tsunami impacts. The State Hazard Mitigation Plan estimates that on the central coast, sea level has the potential to rise between 1.38 and 5.48 feet by the year 2100 (CA OES, 2013). This could increase the damage created by a tsunami not just by increasing runup height, but also by causing the erosion of natural protective structures like beaches and bluffs.

Because of the relatively benign history of tsunamis in most of California, the risk to the state has been given little regard for years outside of scientific circles. Then the Pacific wide damage from the 2011 tsunami called everyone's' attention to tsunami risk in California. Since then there have been serious efforts in the state to increase tsunami mapping and mitigation efforts as well as to study possible impacts. California is now on the cusp of adding tsunami mitigation to various state laws.

Technical studies of tsunami modeling and hazard analysis are currently being carried out to determine probabilistic tsunami return intervals that will be developed into tsunami hazard maps; much like how seismic terrestrial hazards are assessed in California. Probabilistic models of tsunamis in California are currently unavailable but are being developed by the California Geologic Survey through the California Seismic Hazard Mapping Act (CGS, 2015). They are considered to provide a better understanding of the hazard than a single "worst case" type of model. The probabilistic 
maps will make understanding a location's risk easier for local decision makers, and tsunami planning.

Additionally future tsunami runup predictions will be more accurate; researchers are developing models that take into account complex local bathymetry and can predict tsunami magnitudes potentially generated by specific faults (CA OES, 2013). Others are working to understand how the dynamic forces of tsunami waves interact with the urban environment (California Tsunami Policy Working Group, 2014). In the future, based on this expanding body of knowledge, there may be federal and state action taken to implement advanced tsunami mitigation. Some of this mitigation could be in the form of subsidized insurance and enhanced building codes. These are both currently being developed: FEMA will soon add tsunami inundation return intervals to their Flood Insurance Rate Maps (CGS, 2015). Also, a national engineering committee is working to establish building design standards that resist tsunamis for incorporation into the International Building Code by 2018 (CGS, 2015).

Additionally FEMA is currently working towards developing a tsunami modeling addition to their HAZUS program (CGS, 2015). The HAZUS program is a publically available, GIS based, multi-hazard risk modeling program. The program is able to assess the physical, economic and social impacts of hurricanes, floods and earthquakes. It can be used to identify vulnerabilities for mitigation before an emergency event occurs or for rapid needs assessments after. Having this program developed for tsunamis will add a significant capability to local planners' ability to assess their tsunami vulnerability.

In addition to scientific research there is a movement to formulate and implement mitigation strategies. An interdisciplinary group of researchers, scholars and policy experts formed the California Tsunami Policy Working Group to study how California can 
prepare for the next tsunami. Their efforts yielded 47 recommendations that shared three goals: build a solid foundation for mitigation, practice risk-based land-use and construction, and enhance emergency management (The California Tsunami Policy Working Group, 2014). If the recommendations can be implemented; California will have tsunami mitigation integrated into many aspects of government including: land use planning, building codes, interagency relationships and university education. Their study presents the state-of-the-art of California tsunami mitigation planning.

There are many resources available for local jurisdictions to use for understanding their tsunami risk and implementing mitigation measures. These tools are well suited for working at a county or regional level, but a gap exists in planning at the community or neighborhood level. The FEMA HAZUS program will help to fill this gap but until the tsunami modeling addition is fully developed, there are other methods that planners can use to assess their community's risk and identify their most vulnerable areas.

The field of quantitatively assessing tsunami vulnerability and loss is young. It is only in the last decade or so that serious research in this field has been accomplished, and there are still unknown factors about how the built environment reacts to tsunami loading and the dynamic forces of waves traveling through the built environment (CA OES, 2013). Though the field is young, there is a usable, validated method to assess tsunami vulnerability: the Papathoma Tsunami Vulnerability Assessment Model. Using this relatively user friendly building vulnerability assessment methodology it is possible to model what affect a tsunami event might have upon the built environment. 


\section{The San Luis Obispo County Local Hazard Mitigation Plan}

San Luis Obispo County has taken active and appropriate steps toward mitigating, or reducing or eliminating long term risk of, tsunamis. There are two County documents governing tsunami mitigation: The San Luis Obispo County Local Hazard Mitigation Plan (LHMP) (2013) and the Tsunami Emergency Response Plan (2011). The San Luis Obispo County Fire Department and CAL FIRE have greatly contributed to the effort by producing detailed inundation area maps that include evacuation routes and other important features.

The San Luis Obispo County Local Hazard Mitigation Plan (2013) includes one section on tsunami risk, and has one map illustrating the Cal OES defined tsunami inundation zone. The map delineates these areas very broadly, simply showing the entire coastal margin of the county as being included in the zone. It states that much of the County is not very vulnerable to tsunamis as many areas protected by wide beaches, dunes, or sea cliffs. Some specific areas that are more vulnerable are called out. They include (among others): Cayucos Creek, Little Cayucos Creek, Old Creek and Willow Creek in Cayucos.

The plan judges the probability of tsunamis affecting the County to be "somewhat likely (between 1 and 10\% chance in a given year)", and states that "limited damage" could occur in impacted areas. Secondary impacts like economic losses and health impacts due to loss of function of facilities and evacuations are rated as "negligible". However, the plan states that tsunamis could result in damage to roads and bridges and could devastate piers, docks, moored boats and agriculture (SLO County, 2013).

The LHMP offers estimates of the potential damages to infrastructure by various disasters including tsunamis (Table 1.). These are worst case scenarios of damage to critical structures and infrastructure. Assuming a 100\% loss of all infrastructure in the 
inundation zone, the estimated potential damage to the county is estimated at $\$$ $2,171,998,000$.. This is the second highest damage estimate of any hazard in the LHMP.

Predictions of tsunami runups are given; citing a 1978 study that indicates the Cayucos/Morro Bay coast could expect 100 and 500 year return interval tsunami runups to be 9.5 feet and 24.2 feet respectively (SLO County, 2013). This is based on a teletsunami generated in the Aleutian Islands or the Chile-Peru trench, arriving at high tide. If a tsunami were to occur during a storm, at high tide, an additional 14.5 feet could be added to its height, producing 24 (100 yr) and 39 foot (500 yr) runups. These predictions are consistent with historical tsunamis measured in other parts of California (SLO County, 2013).

Table 1. LHMP Hazard Damage Estimates

\begin{tabular}{|l|r|l|r|}
\hline Hazard & Total Building Replacement Value & $\begin{array}{l}\text { Estimated } \\
\text { Percent } \\
\text { Damage }\end{array}$ & $\begin{array}{l}\text { Estimated } \\
\text { Potential Damage }\end{array}$ \\
\hline Earthquake & $2,990,415,000$ & $100 \%$ & $2,990,415,000$ \\
\hline Flooding & $764,145,000$ & $50 \%$ & $382,072,500$ \\
\hline Wildfire & $2,170,833,000$ & $25 \%$ & $542,708,250$ \\
\hline Tsunami & $2,171,998,000$ & $100 \%$ & $2,171,998,000$ \\
\hline Adverse Weather & $2,685,515,000$ & $10 \%$ & $268,551,500$ \\
\hline
\end{tabular}

Slo County LHMP 2013

Other hazards relating to tsunami impacts discussed in the LHMP include earthquakes and coastal erosion. Earthquake potential in the County is high. There are many active and inactive faults in the County, and four surrounding Cayucos: the Cayucos, Oceanic, Cambria and Hosgri fault zones. The Cayucos fault zone is directly beneath the town but considered inactive, with a low potential of fault rupture hazard. The Oceanic fault is considered a moderate fault rupture hazard, but is several 
kilometers north of town. The Cambria fault is also a moderate fault rupture hazard and is mapped as going offshore north of Cayucos and returning to shore as a broad zone of faults that pass through the town (SLO County, 2013). The LHMP states that the further study of the Cayucos fault is needed prior to allowing structures to be built near the mapped fault traces. The Hosgri fault system is located offshore, running parallel to the coast, and is capable of producing up to a 7.3 magnitude earthquake (SLO County, 2013). It has been included in a HAZUS seismic risk assessment scenario in the LHMP, but its tsunamigenic capacity was not evaluated or considered.

Coastal erosion is also a hazard in Cayucos. It is a complex issue that involves local geology, exposure to wave energy, sea level rise and the built environment. Based on these factors, coastal areas in SLO County are exposed to varying levels of erosion. As coastal erosion takes place it can cause the retreat of bluffs and undermine oceanfront structures. FEMA predicts that erosion may destroy one of every four houses within 500 feet of the shoreline in the next 60 years (SLO County, 2013). In addition to direct loss, coastal erosion can expose more structures to hazards associated with the water front, like tsunami inundation.

In Cayucos many oceanfront homes are built on bluffs that are composed of easily erodible Franciscan Mélange rock formations (SLO County, 2013). There is a high erosion potential: an average year can see 6 to 10 inches of erosion, and during a 1983 storm some bluffs eroded as much as 20 feet inland (SLO, County, 2013). Additionally, downtown Cayucos is built on unconsolidated riverine sediment, and is also very susceptible to shoreline erosion.

The County has adopted tsunami mitigation measures via the LHMP that seek to minimize the level of damage that could be inflicted. These apply to Cayucos and include: 
1. Provide the coastal cities assistance in updating their tsunami plans, maps, and evacuation processes.

2. Provide training to appropriate agencies on changes to tsunami emergency plans and pre-response plans and policies.

3. Maintain emergency responder pre-response plans for ongoing tsunami inundation areas.

4. Install tsunami area warning signs (deferred).

\section{TsunamiReady ${ }^{\circledR}$}

Additionally the County is in the process of becoming TsunamiReady $\AA_{\text {. }}$

TsunamiReady $\circledast$ is a voluntary tsunami mitigation program administered by The National Weather Service that focuses on raising a community's level of preparedness through educating emergency managers and the public about tsunami risk and improving communications and emergency response plans. Becoming TsunamiReady ${ }^{\circledR}$ ensures preparedness, confers recognition upon a community, and can put a community in an improved position to receive federal and state grant funds. To become TsunamiReady $\AA$ a community must meet standard guidelines that are scaled to reflect the size of the community. Since Cayucos is an unincorporated town, under the jurisdiction of San Luis Obispo County, it is up to the county to implement the program, at a county wide level. San Luis Obispo County is currently working with NOAA to become TsunamiReady® (E. Boldt, NOAA, personal communication, May 18, 2015). This certification will also cover other unincorporated coastal towns in the county like Avila Beach and Cambria.

Appendix B details the guidelines that must be attained, many of which are already met. Cayucos is currently tied into the county's warning siren system and covered by county emergency response plans. The TsunamiReady ${ }^{\circledR}$ program will provide educational programs as well as tsunami warning signs in Cayucos. 
Meeting the guidelines and becoming TsunamiReady ${ }^{\circledR}$ is a strong effort on the part of the county to prepare for tsunamis and prevent the loss of life. It is a relatively easy mitigation tool to implement as it does not require spending large amounts of funds for building projects like some other mitigation methods do. Nor does it require the use of potentially unpopular policies to accomplish, like some tsunami planning land use decisions might.

\section{Tsunami Emergency Response Plan}

The SLO County Tsunami Emergency Response Plan is an appendix to the SLO County Office of Emergency Services Emergency Response Operations Plan. The document repeats much of what is written in the LHMP but offers more detail about possible effects of tsunamis, these include:

- Mass injuries

- Emergency medical services disruptions, including hospitals

- School disruptions

- Hazardous materials releases

- Fires

- Need for short term evacuations

- Utility disruptions: gas, electric, water, sanitation

- Transportation system disruptions

- Traffic management problems

- Communication disruptions

- Disease and health hazards

- Loss of commerce and government resources

The Tsunami Emergency Response Plan cites a study done by the University Of Southern California (for Cal EMA) estimating a general maximum tsunami runup on the coast of SLO County being 40 feet $(12.1 \mathrm{~m})$ above mean sea level. With this number in mind the county established an evacuation zone of all coastal areas below 50 feet in elevation, providing a ten foot elevation buffer between the estimated maximum inundation level and the limit of the evacuated area. Sea level rise will amplify the 
impacts of tsunami runup in the future and cause this estimate to be an underestimation in terms of runup above sea level and also the area inundated

\section{SLO Fire Department Inundation Maps}

The SLO County Fire Department and CAL FIRE developed a series of detailed tsunami inundation maps for use by emergency responders (Appendix 1.). The Northern Cayucos Tsunami Planning map (2011) offers this about the community's situation:

This small town has ingress and egress points at Highway 1 (north and south) and Old Creek Rd to the east. The northern end of the town is expected to incur major damage in the event of a large tsunami. The downtown area, including fuel stations, schools and the local fire station are all well within the inundation zone, as are many homes along the low-lying beach front properties.

These maps have been made available to emergency responders and can be viewed on the SLO Fire Department's website, but are otherwise not generally circulated.

\section{Cayucos and the Need for This Study}

Cayucos is a small beach community on Estero Bay in San Luis Obispo County (Appendix C.). The economy is tourism based and the community is a peaceful, family friendly getaway, popular with people from cities or inland areas. The laidback downtown area fronts the ocean and has restaurants, cafes, wine tasting, hotels and surfboard rentals. A historical pier is located in the downtown and serves as an attraction and landmark. The population of the community is listed as 2,475 in the 2013 U.S. Census; however this number fluctuates by an unknown number seasonally as visitors and part-time residents come and go. The downtown is low lying and much of the community's business district as well as the fire station, gas station, pier, and hotels are located in the 500-year inundation zone. Also, hundreds of homes along the shore are at risk. 
It is recognized in the LHMP and the SLO County FD inundation maps that Cayucos is at elevated risk to tsunamis. The map produced by Cal Fire and the SLO County Fire Department is very detailed and valuable for understanding generally where the hazard zone is in Cayucos. However, to better understand which specific areas in the community are the most vulnerable, a more in depth type of study is needed, and the small size of the community makes this level of analysis practical. 


\section{Methodology}

The method used in this study to assess the community's tsunami vulnerability is the Papathoma Tsunami Vulnerability Assessment Model (PTVA). This method for calculating tsunami vulnerability and maximum loss was developed in the early 2000 s by Maria Papthoma-Kohle and Dale Dominey-Howes (researchers from the Universities of New South Wales and Vienna respectively) (Dominey-Howes et al., 2007). It has been validated, or ground truthed, by field research in the wake of the 2004 Boxing Day tsunami. After the tsunami, researchers visited South Male' Atoll in the Maldives and found that tsunami damage closely correlated with PTVA estimations (Dominey-Howes et al., 2007). The model has since been peer reviewed and applied in the Greek Islands and Seaside, Oregon.

The PTVA model takes into account physical factors that influence a building's survivability during a tsunami, and rates the building's overall vulnerability. Factors that influence vulnerability include: inundation depth, building row number (from the water), construction material, number of floors, building orientation, condition of building, building surroundings and land cover. These attributes have been identified, through analysis of tsunami damage assessment surveys and engineering reports as being the most important factors affecting building survivability (Dominey-Howes et al., 2010).

Table 2 summarizes the attributes in weighted order as used in the study. The scale follows a logical progression with a buildings level of exposure to inundation ranking as more important than anything about the building itself. The two most highly weighted attributes relate to the level of exposure and include Inundation depth and the building's row from the sea. These attributes categorize how high the inundation is and how many buildings are in the way to bear the brunt of the wave force. These are the main determinants of building survivability. The other attributes related to building 
material, design and surroundings are considerably less important, but in aggregate can serve to influence survivability.

The model assigns a score to each attribute. Buildings are inspected and raw scores taken for each attribute. Raw scores for the eight data fields are converted into ratios for comparison by dividing the individual score by the highest possible score for that data field. This results in a standardization of scores to between 0 and 1 for each data attribute. Next these ratio scores are weighted according to the weighting scale developed by Papathoma and her associates' expert judgement. To do this the ratio scores for each attribute are multiplied by the weight associated with that attribute, they are then summed. Where "a,b,c,d,e,f,g, and h" are the ratio scores of each attribute: Vulnerability $=(8 x a)+(7 x b)+(6 x c)+(5 x d)+(4 x e)+(3 x f)+(2 x g)+(1 x h)$

The overall scores are then separated into five equal intervals to create a vulnerability scale that ranges from low, medium low, medium, medium high to high. These ratings represent predictions of relative vulnerability to damage, and not specific damages. In the PTVA model, buildings that score "high" and "medium high" are considered to be complete losses. Inundation depth is the most important factor in deciding vulnerability, and those buildings that score "high" and "medium high" are largely associated with higher inundation levels ( $>4$ meters). Those buildings that receive lower vulnerability scores would certainly sustain damage during a tsunami, but would likely be repairable (Dominey-Howes et al., 2010).

While the original PTVA has been validated in the field after the 2004 Indian Ocean tsunami, meaning that its results have roughly correlated with actual damages, it is a first generation assessment tool. There have subsequently been criticisms of, and suggested improvements to, the model. A common criticism of the original PTVA model 
is the manner in which attributes are weighted. The original model relies on the "expert" judgement of its creators to weigh attributes. Other researchers have developed a revised model of the PTVA and used "M-Macbeth" software in an attempt create a more accurately weighted scale. This program allows a panel of experts to input their individual weighting judgements, and then verifies their consistency and generates a rated scale. This process produces a more accurate product with less subjectivity than the original model. Also, researchers have suggested adding other building attributes to the model such as: the presence of outdoor movable furniture, type of ground level windows, foundation type, and insurance policy adequacy (Dall'Osso et al., 2009). It would have been possible to add some of the additional attributes to the model for this study, but others, like the foundation type (the presence or absence of a basement), or insurance policy adequacy would be impossible to assess without entering buildings or interviewing building owners. This would have been impossible to accomplish given the number of buildings involved and the limited time allocated for the study. There have been no published statistical comparisons of results between the original model and the amended models to suggest that they offer significant benefits.

Additionally, some researchers criticize the PTVA model because it does not account for the force of the tsunami itself and how it changes when encountering an urban environment. These forces are undeniably very important to the vulnerability equation. To attempt to address this, researchers are currently developing fragility curve models to account for the dynamic forces of water against buildings. These models relate water depth to the probability of structure failure and will allow for more accurate building damage assessments (Wiebe, 2014). Given the current absence of usable fragility curve models and limitations of time that this Cayucos study faced, and that the updates to the model have not been proven to be any more accurate than the original, it 
was decided that the original PTVA would give sufficiently accurate results for the planning purposes that the project was intended for.

The study was completed in 3 general steps.

1. GIS analysis to determine the flood area and the average water depths for each building.

2. Data collection and application of the PTVA model.

3. Analysis of the data. 
Table 2. PTVA Attributes in Descending Order of Weighted Importance

\begin{tabular}{|c|c|c|c|}
\hline Attribute & Attribute description & $\begin{array}{l}\text { Vulnerability } \\
\text { descriptor }\end{array}$ & Raw Score \\
\hline Inundation level & $\begin{array}{l}\text { The averaged level of } \\
\text { water in each building }\end{array}$ & High to low & $0-12.1$ \\
\hline $\begin{array}{l}\text { Builing row from } \\
\text { ocean }\end{array}$ & $\begin{array}{c}\text { How many rows of } \\
\text { buildings between a } \\
\text { paticular building and the } \\
\text { ocean }\end{array}$ & High to low & 1 to 12 \\
\hline $\begin{array}{l}\text { Building } \\
\text { material }\end{array}$ & $\begin{array}{l}\text { Wood only; wood on } \\
\text { concrete base; } \\
\text { steel frame with wood } \\
\text { walls } \\
\text { Stone and concrete; } \\
\text { concrete and brick }\end{array}$ & $\begin{array}{l}\text { High } \\
\text { Medium }\end{array}$ & 2 \\
\hline & Reinforced concrete & Low & 1 \\
\hline Number of floors & $\begin{array}{l}\text { One floor } \\
\text { Two or more floors }\end{array}$ & $\begin{array}{l}\text { High } \\
\text { Low }\end{array}$ & 2 \\
\hline $\begin{array}{l}\text { Building } \\
\text { Orientation }\end{array}$ & $\begin{array}{l}\text { Cubic/parallel to shore } \\
\text { Cubic w/ corner to shore } \\
\text { Irregular; hexagon, round } \\
\text { etc. }\end{array}$ & $\begin{array}{l}\text { High } \\
\text { Medium } \\
\text { Low }\end{array}$ & $\begin{array}{l}3 \\
2 \\
1\end{array}$ \\
\hline Building Condition & $\begin{array}{l}\text { Poor; unmaintained, } \\
\text { abandoned } \\
\text { Fair; somewhat decayed } \\
\text { but habitable } \\
\text { Excellent; newer } \\
\text { construction }\end{array}$ & $\begin{array}{l}\text { High } \\
\text { Ledium } \\
\text { Low } \\
\end{array}$ & 3 \\
\hline $\begin{array}{l}\text { Building } \\
\text { Surroundings }\end{array}$ & $\begin{array}{l}\text { No barrier } \\
\text { Low/narrow earth } \\
\text { embankment } \\
\text { Low/narrow concrete } \\
\text { wall } \\
\text { High Concrete wall }\end{array}$ & $\begin{array}{l}\text { Very high } \\
\text { High } \\
\text { Medium } \\
\text { Low }\end{array}$ & 2 \\
\hline Land cover & $\begin{array}{l}\text { None } \\
\text { bushes and low trees } \\
\text { Large trees }\end{array}$ & $\begin{array}{l}\text { High } \\
\text { Medium } \\
\text { Low }\end{array}$ & 2 \\
\hline
\end{tabular}




\section{GIS Analysis}

To complete the study it was necessary to delineate the extent of the theoretical tsunami runup in Cayucos, and then to calculate an average water depth for each building. Water depth is the most important factor in determining building survivability using the Papathoma Method. All of the files needed for the project were available on the Cal Poly Kennedy Library's GIS server.

First San Luis Obispo County data was obtained from the Cal Poly Library GIS server. Files obtained included: DEM and hillshade raster files, parcel, mean shoreline, roads and a building footprint (incomplete) vector shapefiles. The buildings layer from the county was missing over a hundred residential structures. These were added to the layer by overlaying the building layer onto a satellite image to view the buildings as they are, and drawing in the missing buildings.

The DEM and hillshade files covered the entirety of SLO County and were very large and slowed down computing speed. They were clipped to just the Cayucos area to increase processing speed. This was done by making a 1,200 foot right side buffer from the mean shoreline shapefile. Then the "extract by mask" tool was used to clip the raster files to that buffer. The result was a smaller file that was easier to work with.

Next the "raster calculator" tool from the "Map Algebra" toolbox was used to add the tsunami runup projection taken from the SLO County Tsunami Emergency Response Plan $(12.1 \mathrm{~m})$ to the DEM. This runup estimation was used because it is the most recent projection used by SLO County, and represents a worst case scenario. This study was done with SLO County in mind as a client, so using their accepted runup estimate maintains consistency between county planning documents. 
Then the "minus" tool was used to subtract the $12.1 \mathrm{~m}$ from all of the areas on the DEM greater than $12.1 \mathrm{~m}$ in elevation. This resulted in a "bathtub" type of flood model, where all areas under 12.1 meters on the DEM are filled in. Now the model showing runup was complete, and it remained to find out the water depth per parcel.

The "zonal statistic" tool was used to do this. This tool averaged the water depth in each parcel, which could then be associated with the buildings on those parcels. To make this data usable it had to be converted to a vector format. This was done by using the "feature to point" tool to convert the buildings layer to centroid points instead of polygons. Then the "extract values to points" tool was used to add the DEM's averaged runup depth to the building centroid. The resulting map shows the average expected water depth for each building (Figure 1.).

Figure 1. Averaged Inundation Depths in Downtown

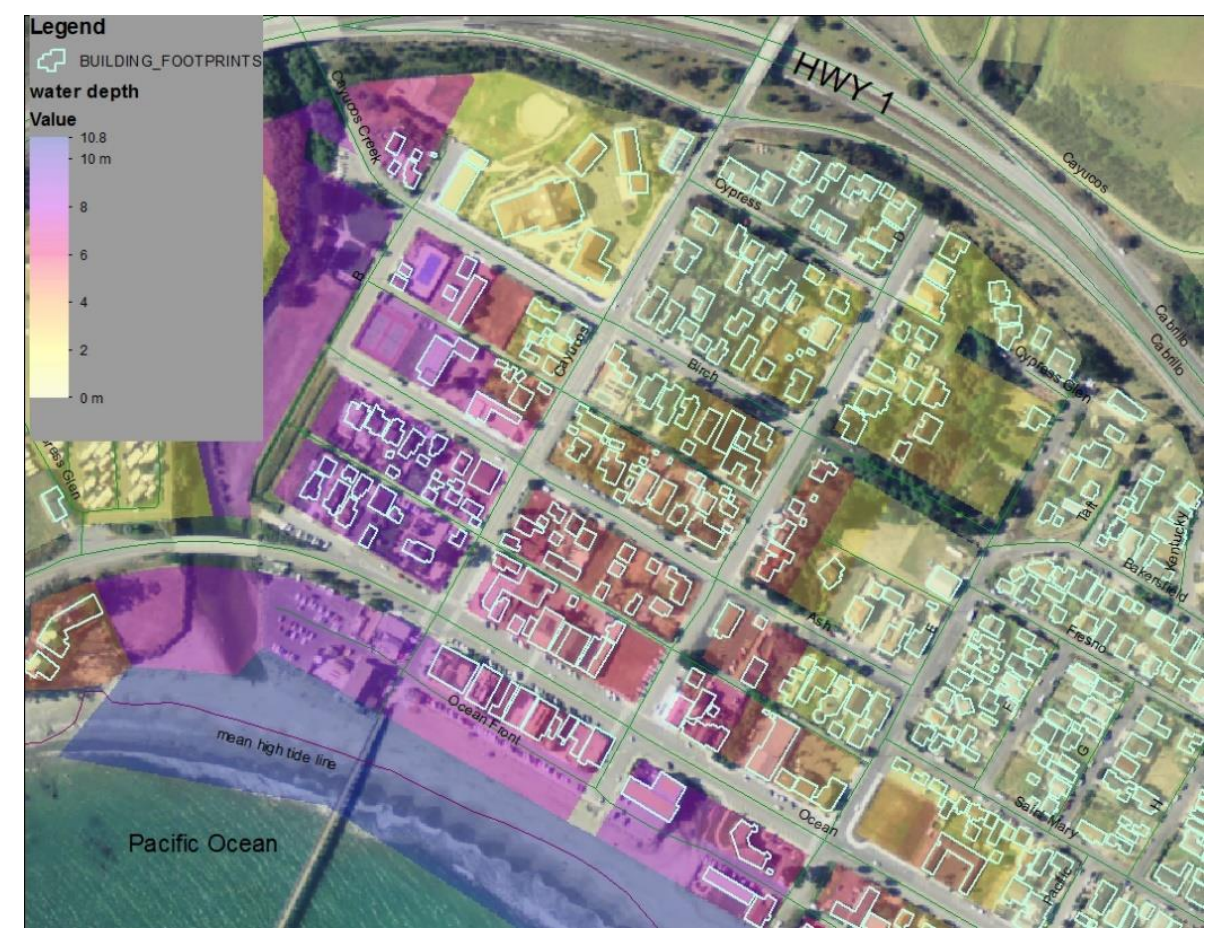


Accuracy of the runup modeling was ensured by creating a topographic layer from the original DEM using 2 meter isolines. Using this it was possible to visually verify that the runup raster layer went as far inland as the 12 meter isoline. This same visual inspection was done using a SLO County supplied topographic layer. In both cases the runup model was either near or in line with the two different topographic layers' 12 meter (40 foot) lines. A series of eight GPS points were also taken using a TopCon GPS unit at prominent street corners in Cayucos to ensure the layer's spatial accuracy on the ground.

\section{Data Collection and Analysis}

There are 745 buildings located in the study area's 500 year inundation zone. Of these, 700 are private residential buildings; the remaining 45 are various commercial and government buildings in and around the downtown. Some are historical buildings, but the majority are of relatively modern construction. A preliminary inspection of the residential areas revealed that these buildings are largely similar in construction material, size, and shape. To speed the collection of data, Google's Street View program was used to assess these buildings. Google's Street View offered current images of the area that could be used in conjunction with GIS, and allowed for effective surveying in these more homogeneous areas. Surveying the downtown area of Cayucos was done on foot. Also, on the ground data collection was used to resolve data issues as they arose. Field data was collected using hard copy data sheets (Appendix D.) and later entered into an Excel spreadsheet. Data collected via Google Street View was directly entered into the spreadsheet. Data collected was based on the PTVA model and included:

Water depth (a), weight=8- based on GIS projections, the average water depth for each building was automatically assigned. While the tsunami modeled for this study was one 
with 12.1 meter runup. The water depth that actually reached buildings was found to range from 0 to 8.4 meters in buildings in Cayucos.

Building row from the ocean (b), weight=7- data collected for this field was based on a building's location relative to the ocean. Data was coded with a score of 12 equaling the first, ocean front row. Subsequent inland rows were assigned scores in descending order to zero. In places the layout of the community is somewhat unorganized and rows of buildings are staggered or not well defined. In these cases a building's score was based on how many buildings are between it and the ocean.

Building Material (c), weight=6- Reinforced concrete construction is the least vulnerable, followed by masonry or concrete block; wooden buildings rate as the most vulnerable. The majority of the buildings in Cayucos are clearly of wood construction. Others have a stucco veneer. Common in California, these homes often have a wood frame with a thin veneer of concrete lining the outer walls. A problem with this is that, viewed from the street, it may not be possible to tell if a stucco home is of wood frame, cast concrete, or concrete block construction.

For this study it was assumed that these homes have a wood frame and were classified in this most vulnerable class. The PTVA method does not account for this type of construction and how these types of buildings perform during a tsunami is unknown. It is possible that the stucco veneer could aid in preserving structural integrity by resisting wave forces during a tsunami, but further research is needed to determine where these types of buildings fall on the vulnerability scale.

Number of floors (d), weight=5- The number of floors not including attics. Second stories can aid in "vertical evacuation" of residents during floods and tsunamis. 
Building orientation (e), weight=4- The orientation of a building relative to the ocean. A cubic building with walls parallel to the shore is the most vulnerable. Those with a corner to the ocean or irregular in shape are somewhat less vulnerable as they receive less force from oncoming waves.

Condition of building (f), weight=3- New buildings and buildings in good condition are less vulnerable to damage during a tsunami than unmaintained or dilapidated ones. Most of the buildings in Cayucos are new or otherwise in a good, maintained condition.

Building surroundings (g), weight=2- The presence of durable protective structures can influence tsunami vulnerability. Sturdy, high walls can act to keep water and debris out of buildings. In Cayucos there are few protective barriers in place. Many homes have decorative walls for landscaping purposes, or picket fences. There are relatively few actual walls around buildings.

Land cover (h), weight=1- The rates the ability of the surrounding land cover to lessen tsunami damage. Owing to the aridity of the region, there is a paucity of vegetative cover and few large trees in Cayucos. Most properties were rated in the most vulnerable class for this attribute.

After the GIS modeling and data collection were complete, the PTVA method was closely followed to calculate building vulnerability scores. Raw scores for the eight data fields were standardized into ratios by dividing the individual score by the highest possible score for that data field. This resulted in a standardization of scores to between 0 and 1 for each data attribute.

Next the ratio scores were weighted according to the weighting scale developed by Papathoma. To do this the ratio scores for each attribute were multiplied by the 
weight associated with that field. The weighted scores were then summed to yield an overall "vulnerability" score.

Vulnerability $=(8 x a)+(7 x b)+(6 x c)+(5 x d)+(4 x e)+(3 x f)+(2 x g)+(1 x h)$

"a,b,c,d,e,f,g, and h" are the ratio scores of each attribute. This calculation yielded vulnerability scores between 12.3 and 36 . These weighted scores were then grouped into five equal interval ranges and assigned a corresponding vulnerability rating (Table 3.). According to the PTVA model, buildings that scored "high" and "medium high" were considered to be complete losses. Inundation depth is the most important factor in deciding vulnerability, and those building that scored "high" and "medium high" are largely associated with higher inundation levels (generally $>4$ meters). Those buildings that received lower vulnerability scores would certainly sustain damage during a tsunami, but would likely be repairable (Dominey-Howes et al., 2010). The scale is an estimation of relative vulnerability to damages, rather than an estimation of specific damages. The PTVA model does not account for partial damage or damage to the contents of buildings.

Table 3. Vulnerability Rating Scale

\begin{tabular}{|l|l|}
\hline Equal Interval Score Ranges & Vulnerability Rating \\
\hline $31.3-36$. & high \\
\hline $26.55-31.29$ & med-high \\
\hline $21.8-26.54$ & medium \\
\hline $17.05-21.79$ & med-low \\
\hline $12.3-17.04$ & low \\
\hline
\end{tabular}




\section{Results}

After mapping and applying the PTVA model we see that $32 \%$ of the community's buildings are within the 500-year inundation zone (Figure 2.). These buildings had a range of vulnerability scores from medium low to high that generally correlated with higher ( $>4$ meter) inundation; resulting in a total of $18.5 \%$ of all buildings in Cayucos likely to suffer complete destruction (assuming that all buildings ranked in the high and medium high vulnerability classes will be completely destroyed (DomineyHowes, et al, 2010)). Many of the most affected buildings are also very important ones; downtown businesses as well as civic and government buildings.

The highest vulnerability ratings and inundation levels are found in the low lying downtown area and the residential area along Old Creek. Also, most ocean front homes fall into the medium high classification and are considered total losses by the PTVA assessment model. Within the inundation area we can expect a loss of $56.8 \%$ of all buildings (high and medium-high ratings). Although the medium and medium low rated buildings would escape complete destruction according to the model; they would undoubtedly suffer damages, and the PTVA model does not account for partial damage or damage to the contents of buildings. Also, some notable structures in Cayucos could not be assessed with the PTVA model: a trailer park, water treatment facility, and the pier. 


\section{Figure 2. PTVA Assessment Results}

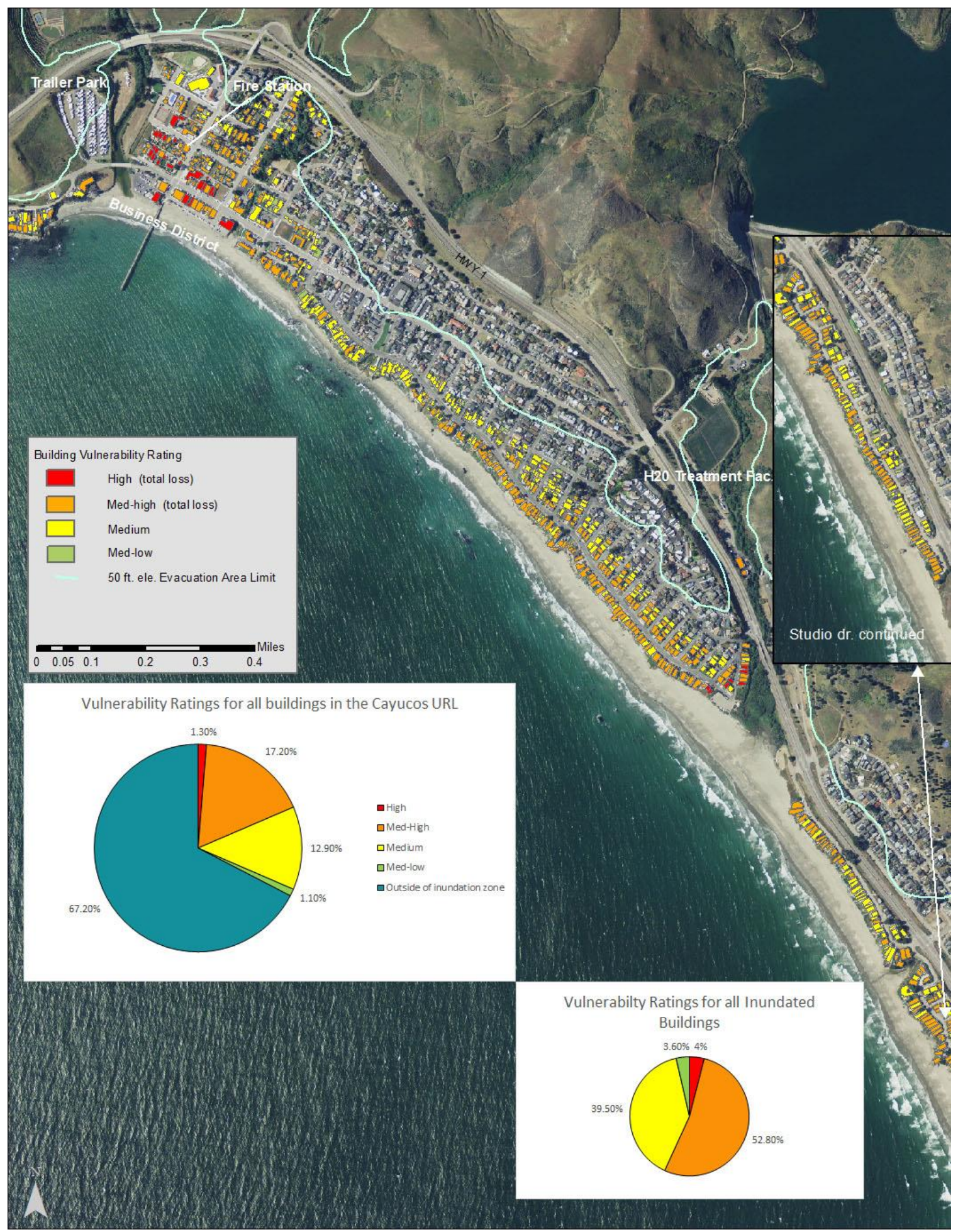




\section{Commercial Buildings and Downtown}

Most of the commercial buildings in Cayucos are in the 500 year inundation zone, and are very vulnerable to tsunami damage. The downtown water front area is low lying and the GIS model predicts inundation of up to 8 meters here. Eighty percent of buildings here scored high and medium high and are likely to be lost (Figure 3.). This represents a serious loss to the community. All of these buildings are in the downtown area and many are tourist attractions such as shops, hotels, and restaurants. The few jobs that exist in Cayucos are tied to these businesses, putting the economic existence of the community at risk. Also, a small gas station is located in the inundation area downtown. Flooding could potentially cause a release of petroleum products, fouling the local waterfront or causing fires (Figure 4.).

Additionally, the small Cayucos fire station scored medium high and is likely to be lost, depriving fire fighters of the use of its facilities and equipment. The station could be rendered totally irrelevant at a time when it is needed the most. There is another fire station, operated by CAL FIRE, on the south side of Cayucos that is outside of the inundation area. This is a small station with limited capabilities, staffed only by a fire captain and one to four fire fighters with one engine (Cal Fire, 2014). This small station is designed to respond to auto accidents and ocean rescues, and may be overwhelmed by an emergency on the scale of a tsunami. The Cayucos elementary school is on the upper edge of the inundation area. Several of its buildings scored medium in the vulnerability assessment, and others are actually outside of the modeled inundation zone. 
Figure 3. Commercial Building Vulnerability

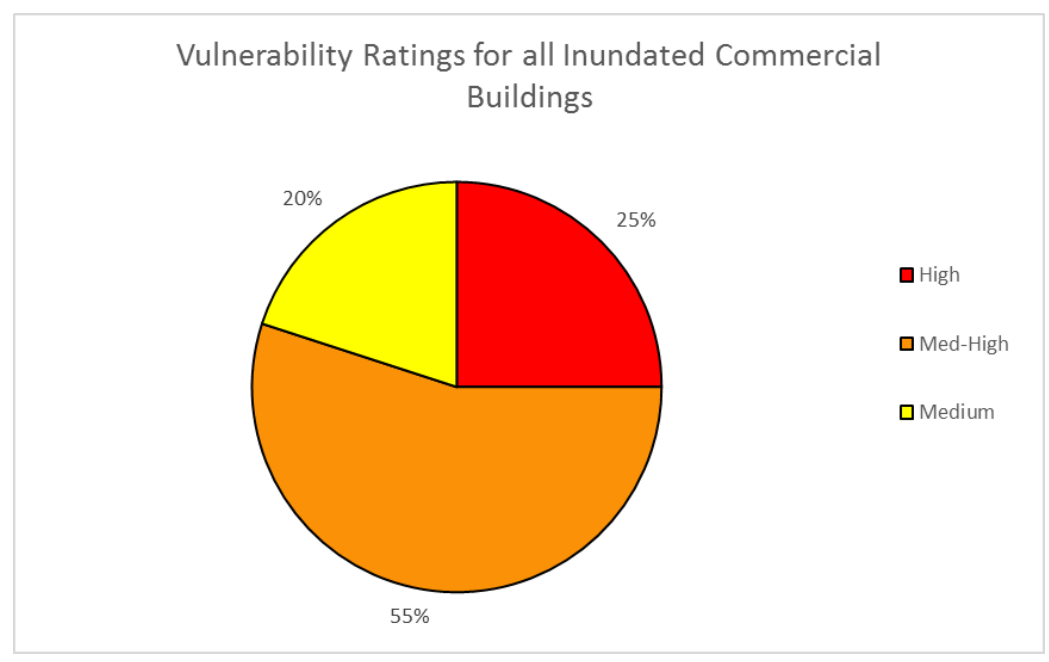

Figure 4. Downtown Cayucos Building Vulnerability

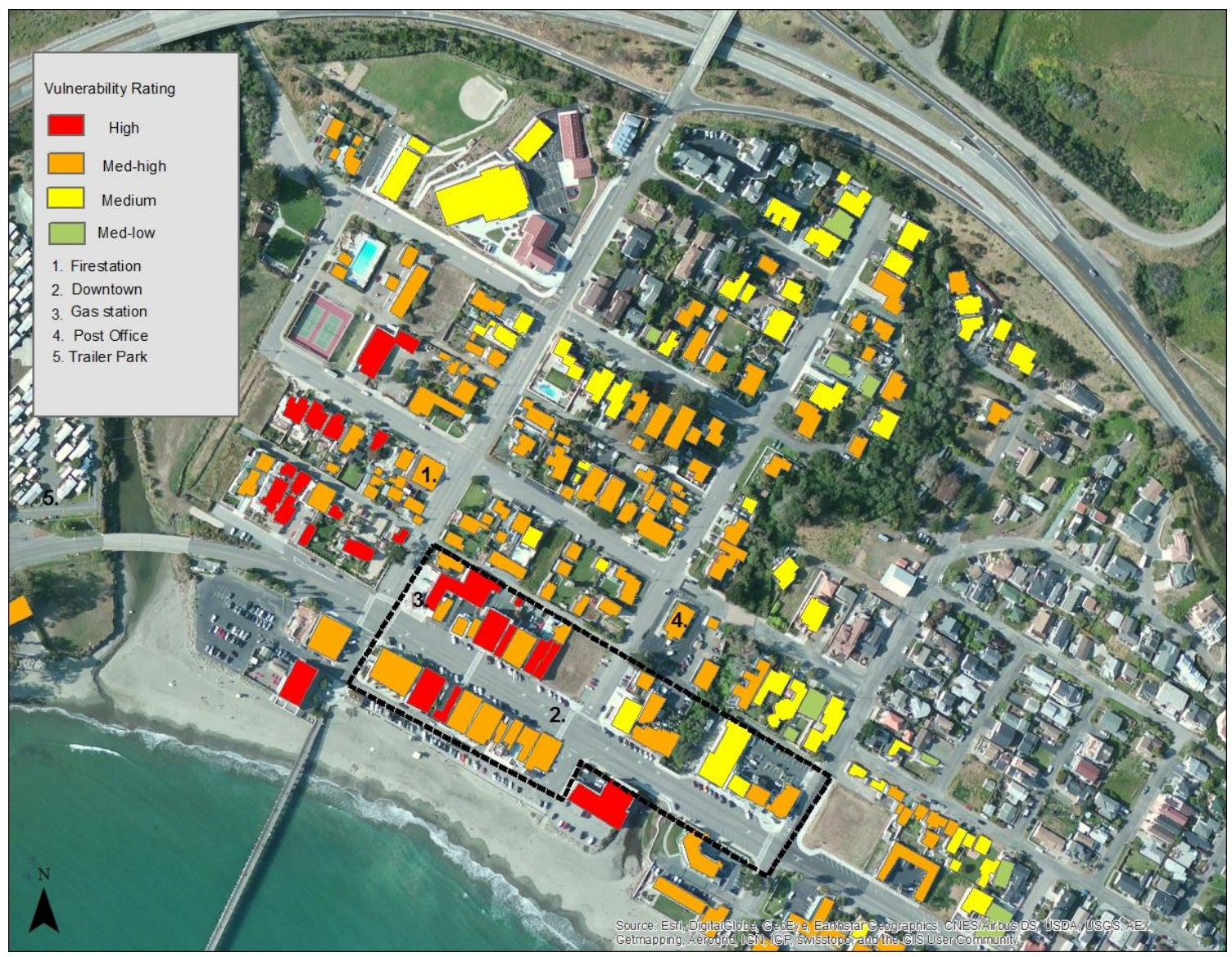




\section{Housing}

Houses in the inundation area are very vulnerable. Homes in Cayucos are generally one and two story, of wood frame construction, parallel to the ocean and without much vegetation or protective structures around them. There is nothing about many of them that afford any tsunami resistance. A total of $55.8 \%$ of houses scored high and medium high on the vulnerability scale. No houses in the inundation area rated low, and very few (3.7\%) rated medium low (figure 5.). Given a 500 year tsunami event with a 12.1 meter runup, all of the houses in the inundation area would suffer damage, and about half would be total losses.

According to the 2010 U.S. Census the average household size in Cayucos is 1.97 people per household. Multiplying this figure by the 700 homes affected leads to the conclusion that 1,379 people might potentially be put out of their homes. Since $55.8 \%$ of homes are expected to be completely destroyed 769 people may be left permanently homeless. However, an unknown (but likely significant) percentage of houses in Cayucos are known to be either second homes or vacation rentals. Depending on whether the actual tsunami struck during tourist season or a weekend or holiday, the number of displaced could be higher or lower than the estimated 1,379. Also, given that some houses in Cayucos are second homes the actual number of people left permanently homeless is likely to be less than 769 . 
Figure 5. Housing Vulnerability

\section{Vulnerability Ratings for Inundated Residential}

\section{Buildings}

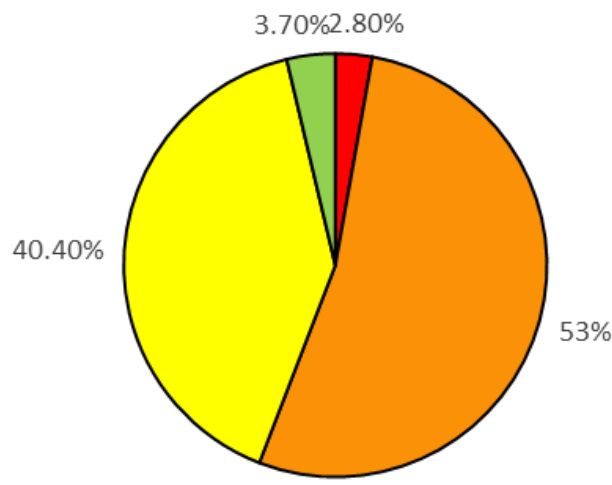

\section{Other Vulnerable Areas}

- A trailer park is located on the bank of Cayucos Creek, a vulnerable area, but was not included in the study's PTVA assessment as trailers are not accounted for in the original methodology. Given their light construction and lack of foundations, trailers are undoubtedly highly vulnerable to tsunamis, and in the event of one striking many trailers would be lost. Also, as they are not permanent structures, the number of trailers in the trailer park can vary, making accurate accounting difficult. Approximately a third of the trailer park is within the modeled inundation zone.

- The Cayucos water treatment facility is located a short distance from the ocean, up Old Creek. The facility consists of a large, circular tank, a few metal buildings and settling ponds. These buildings were not suitable for analysis with the PTVA method. However the tsunami inundation model indicates the possibility of 4.7 
meters of water in this area, making it unlikely that the plant could continue operations or remain intact. The flooding of this facility could result in the loss of drinking water for all of Cayucos and possibly the contamination of Old Creek with chemicals.

- The iconic Cayucos pier, central to the community's identity and appeal to tourists, is located downtown at the mouth of Cayucos Creek. It is over a hundred years old and built of wood. The SLO County LHMP states that docks and piers are very vulnerable to tsunami damage. Given its material and age, it is unlikely to survive inundation by the 12.1 meter tsunami modeled in this assessment.

- There are several bridges in and around Cayucos that could be vulnerable to damage during a large tsunami. These include Ocean Avenue bridge, Old Creek bridge, and Torro Creek bridge. If these were impassible following a tsunami it would seriously impair relief and recovery efforts.

\section{Modeling a More Resistant Community}

A strength of the PTVA model is that it is dynamic. Attribute scores can be manipulated to calculate different theoretical outcomes. For example, since the majority of the buildings in Cayucos are built of the most vulnerable material (wood, raw score 3) and also oriented in the most vulnerable way (parallel to the ocean, raw score 3) we can change the scores in these attribute fields to model a scenario in which the study area's buildings are built of more sturdy materials, and with a less vulnerable orientation. To do this, raw scores for the building material and orientation attributes were changed from 3's to 2's, and the scores recalculated. The result allows for a view into how building attributes, like those governed by building codes, might influence the community's overall survivability. 
Modeling the new scenario we see quite a different outcome in vulnerability ratings (figure 6. and 7.). The new hypothetical Cayucos is far less vulnerable to a 500 year tsunami. Owing to the increased durability of materials and building orientation that attenuates wave force, the number of buildings in the most vulnerable building classes (high and medium high) are reduced by $71.9 \%$ (58.8\% to $16.5 \%)$ in the new model. By avoiding wood structures and parallel orientation to the shoreline, the model suggests that significant gains in overall survivability can be attained. This in no way substitutes for an in-depth structural engineering study of tsunami resistant building design. Rather, it roughly indicates what gains in survivability could be attained through building design, and the results are dramatic. Adopting special building codes for tsunami prone areas could be a positive long-term mitigation strategy in SLO County. 
Figure 6. Revised Vulnerability Ratings for a Theoretically More Durable Cayucos

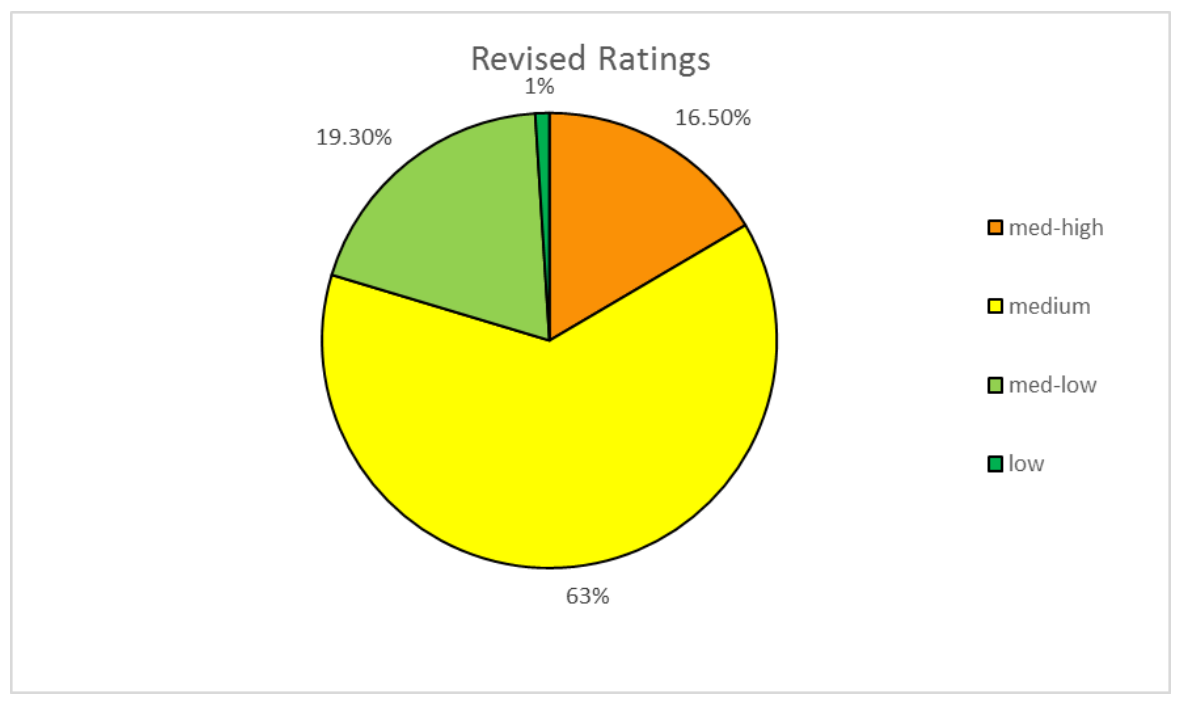

Figure 7. The Study's Original Results

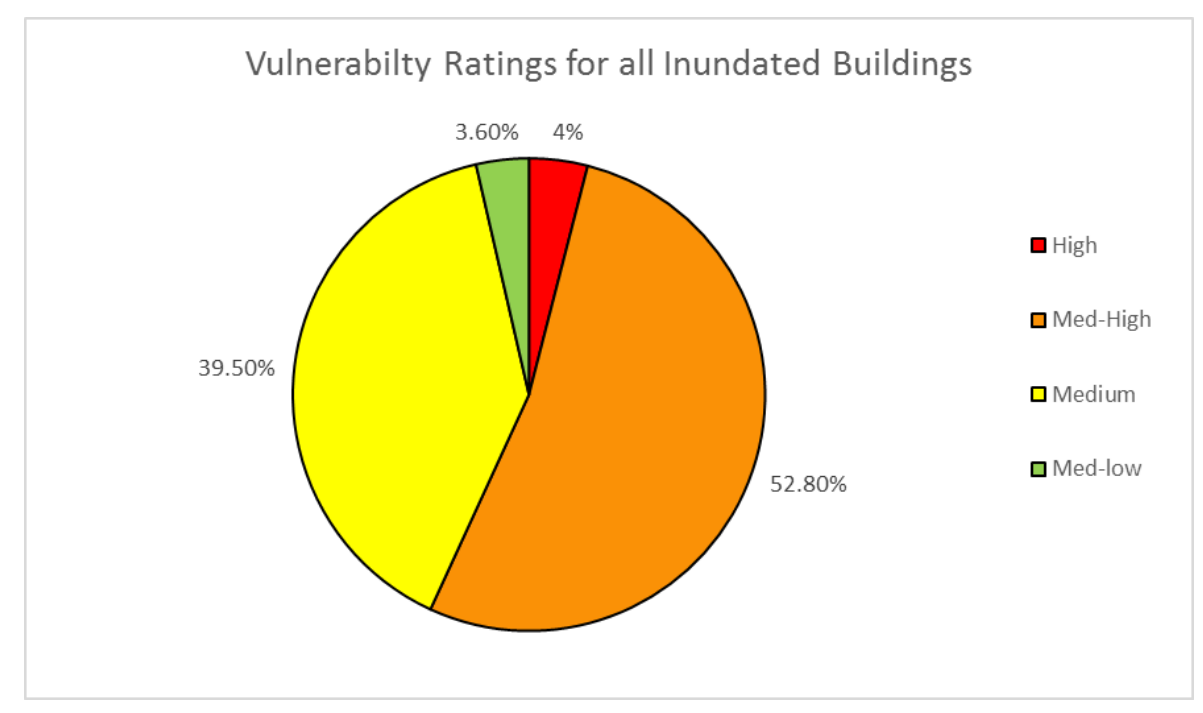




\section{Conclusion}

\section{The PTVA's Pros and Cons}

The PTVA model goes into far greater detail than studies in existing state and local hazard mitigation plans. It proves to be a user friendly, useful tool to delineate the most vulnerable areas, down to the individual building, and to discover probable tsunami impacts. However the PTVA model does have limitations.

One limitation with the model is the time consuming data collection and ground truthing inherent to it. Cayucos is small enough to complete a 100 percent sample of buildings in the inundation area. However in other communities there could be thousands of buildings to assess, making a 100 percent sample lengthy, if not impossible. The alternative to a 100 percent sample is taking a representative sample and then using inferential statistics to calculate scores for the un-sampled buildings.

Another limitation is the classification of building materials used in the model. The model only accounts for three classes of material:

1. Wood frame, steel frame with wood walls

2. Stone and concrete and brick

\section{Reinforced concrete}

In the Cayucos there are many buildings that have a stucco veneer, and fell in no obvious category. The PTVA model was not developed in California, and does not reflect common local construction methods. The building material attribute must be correct for types of construction in the region that it is being used in. An expanded palette of material classes would be a great improvement to the model. 
Though the model has been validated in the field by looking at damage caused by actual tsunamis, it should be not be relied on as a definitive prediction of damage. There are many factors affecting how tsunamis are generated and interact with the urban environment; some of which have yet to be understood. The model also depends on using runup predictions that do have the chance of being exceeded, perhaps dramatically. The 2011 tsunami in Japan showed that tsunami and earthquake events can exceed predicted levels of magnitude. Additionally, the exceedance of these estimates will be more likely as sea level rise impacts the coast (up to 5.48 feet). It cannot be stressed enough that findings in this type of study are estimates for planning purposes and not precise predictions of damage.

\section{Planning Discussion and Recommendations}

Despite any shortcomings inherent to the PTVA, this report has gone into a much deeper level of study than any existing documents about the area's tsunami vulnerability. This, in conjunction with the LHMP, Tsunami Emergency Response Plan and CAL FIRE's tsunami planning map allow for a more than basic understanding of the community's tsunami vulnerability. In the future our understanding will continue to grow with the development of probabilistic tsunami modeling, and building fragility curves.

There are many things that could be done to mitigate the hazard detailed in this study. Efforts can range from large, capital intensive building projects to the institution of educational programs. Deciding just what measures to take and striking a balance between costs and benefits associated with planning for a 500-year return interval tsunami is a considerable challenge. Planning for a 500-year return interval tsunami has already been done by the county; evacuation areas were based on 500-year runup estimations. Some more extreme mitigation measures may simply not be politically possible given the limited risk of the hazard and budgetary constraints. Deciding what 
further measures to take could benefit from an ongoing discussion with Cayucos residents to gauge their perception of the risk.

Ideally we could avoid new development in tsunami run-up areas to minimize future tsunami losses; but Cayucos is nearly at "build out", especially on the ocean front. There are only a few vacant lots in the inundation area: notably, a handful along Cayucos Creek, two large commercial lots on N. Ocean Avenue in downtown, and several small residential lots scattered in the Pacific Drive area. Limiting the development of these lots for tsunami mitigation by the County is extremely unlikely as it could be politically unpopular and hinder economic development, while purchasing them may be prohibitively expensive.

Focusing on evacuation and education may be the most effective method to limit loss of life during the next tsunami. Evacuating northern Cayucos may not be too problematic. There are excellent maps from CAL FIRE that detail evacuation routes, and a system of warning sirens is in place to issue warnings. Gaining high ground does not require a long drive or walk in Cayucos. A walk of approximately a quarter mile (1300 feet) is all that is required to exit the inundation area from anywhere in downtown. The residential areas along Pacific Avenue require an even shorter walk to safety, of about 500 feet, and there are many streets leading inland that offer evacuation routes. Evacuation of these areas is relatively simple as they do not require pedestrians to cross any barriers, like Highway 101 which runs right through the community.

The situation is different in southern Cayucos. Evacuating the inundation area along low lying Studio Drive on foot would require crossing Highway 101. While the distance to safety in this area is not great, the highway offers a serious impediment. In addition to high traffic volume that could be present during a general evacuation, there are also wire fences lining the highway to keep out people and animals. Unless people are willing to jump the fence, crossing the highway on foot requires using one of only 
three roads leading from the highway into the long, narrow Studio Drive corridor. If one could directly cross the highway, the walk to safety would be only 300 to 500 feet. However, traveling to an intersection and then crossing the highway increases the walk to $900-1600$ feet.

Evacuating Cayucos by car may not be a problem for most people; the area has well developed and maintained roadways and generally low traffic. However, bridges on Highway 101 could become impassable in the event of high tsunami inundation. This would cut Cayucos off from emergency services coming from larger cities to the south, and deprive people of what may be their first choice of an evacuation route. Access to the inland cities of Paso Robles and Atascadero would still be available via Old Creek rd. and Highway 46 to the north.

There are many efforts that could be undertaken to educate the public about evacuations, the risk of tsunamis and the potential extent of the inundation area. Teaching people what to do, where to go, and how to get there in the event of a tsunami may be the most efficient mitigation strategy for protecting them. There are simple ways to accomplish this. For example, in Hawaii there are inundation maps published in the local phone books, and signs demarcating tsunami inundation zones in populated areas. Becoming Tsunamiready® will ensure that these types of education materials are available to educate residents about the danger presented by tsunamis, and that local government is prepared to respond.

As the federal and state governments begin to implement tsunami mitigation there are still some local measures that could be taken. Looking to principles from the Tsunami Policy Working Group's 2015 report can provide guidance for further specific measures that could be applied to Cayucos. The principles encourage short and long term strategies, some that incorporate multiple hazards. These include: 
1. Implementing a new building code for inundation areas that ensures tsunami resistant designs for new buildings.

As figures 6 and 7 show, building design has the potential to greatly improve survivability during tsunami inundation. Building codes designed for safety and hazard mitigation are certainly not new in California. They already exist for fire and earthquake resistance. Tsunami resistant building codes would affect relatively few future construction projects (only those within the mapped inundation zone) while increasing the county's resilience to tsunamis. Standards for this are currently being developed. The International Building Code will contain updates for tsunami resistance by 2018 (CGS, 2015). These codes could become mandated by the state if designated tsunami inundation zones are formed. Otherwise it is in SLO County's jurisdiction to implement new building codes in coastal areas.

2. Creating policies for retrofitting public buildings to ensure tsunami survivability, and offer vertical evacuation for residents.

The technology for designing raised, tsunami proof shelters is already developed. Often they are constructed of concrete and steel; or soil in "engineered high ground" that can be incorporated into parks and openspace (FEMA, 2009). FEMA has published a design manual Guidelines for Design of Structures for Vertical Evacuation from Tsunamis, and the west coast's first vertical evacuation structure is under construction in Westport, Oregon. There, a school on a flat peninsula with limited evacuation routes is being built with a raised shelter for students. 
This is a long- term mitigation strategy that could be difficult and expensive to implement. In a place like Cayucos, where ocean views are important to people, the tall structure of a vertical tsunami shelter may block views and be unpopular with residents. The cost of this measure could also be prohibitive in a small community, and the benefit may be marginal. The most vulnerable and densely inhabited place in Cayucos, the downtown, may be evacuated on foot by walking approximately a quarter mile. Assuming that people know what to do in the event of an earthquake and local tsunami it is reasonable to believe that all ambulatory people could make it to a safe area. However, a structure should not be ruled out. Having one would provide shelter to those who may not be physically able to evacuate or if a locally produced tsunami came in with no time for warnings or evacuation by foot. A vertical shelter may make more sense for the Studio Drive area than the downtown, given the greater difficulty involved in evacuating the former.

3. Incorporating tsunami hazards into regional land-use planning and strategies to mitigate climate impacts, such as increasingly intense coastal storms, coastal flooding, and sea level rise.

In Cayucos there are opportunities for tsunami mitigation that could also mitigate coastal erosion and sea level rise. These include:

1. Developing policies to prevent post-tsunami redevelopment of the most vulnerable waterfront parcels.

2. Strengthening the downtown seawall.

After a tsunami has devastated a city, there is the option of not rebuilding in flood prone areas. Hilo, Hawaii as a good example of this. Downtown Hilo used 
to look much like Cayucos with a water front row of commercial buildings. In the 1960 's the most flood prone areas of the city were abandoned after suffering the loss of 219 people and millions of dollars in damage to two tsunamis in the space of fourteen years (Curtis, 2008). This included the waterfront block formerly occupied by commercial buildings. Hawaii County acquired the water front parcels using federal redevelopment funds, and these areas are now open space that serve as a park as well as a buffer against future tsunamis, coastal flooding and sea level rise.

A similar decision was made in New York City in the wake of Hurricane Sandy where extreme flooding affected many coastal residential areas. The governor of New York used Federal Community Development Block Grant Disaster Recovery Program funds to buy and demolish damaged houses in high risk areas, at pre-Sandy prices. He says the land will be "given back to mother nature" to serve as a buffer to future storm surge (Jervey, 2013).

As sea level rises and tsunamis and storm surge come to affect more urban areas, more frequently, we may see a gradual, nationwide retreat from water front properties. One day Cayucos may end up looking like Hilo, with open space in place of its first row of waterfront buildings. After the tragic event of a tsunami, this could be a good option for Cayucos. Not rebuilding the first row of buildings would not only mitigate the effects of tsunamis, erosion and sea level rise on the downtown, but could benefit the community in other ways, by increasing recreation space and enhancing ocean views.

The 500-year tsunami modeled in this study may not strike for hundreds or thousands of years, making the policy of preventing rebuilding a moot point at this time. However, sea level rise and increased vulnerability to erosion and 
storm surge are here today. Building a modern, concrete seawall may be a good investment to protect the first block of oceanfront buildings and downtown from future flooding. Properly designed and built seawalls have been shown to limit tsunami damage to areas behind them (Dominey-Howes, 2007), and can provide protection against tsunamis as well as sea level rise and coastal erosion (CA OES, 2013).

The current seawall in downtown Cayucos appears to have been built in stages over the years. It consists of four sections of varying heights and materials: the southernmost and northernmost sections are low rock rip-rap, while the middle is divided in two halves composed of concrete approximately two meters high, and cinder block about one meter high. The seawall seems to have been adequate until now, but as sea level rises up to five feet in the next century, increased erosive forces could act on the beach. As this beach erodes more wave force will begin to act upon the seawall, and the more weakly constructed sections of the wall could fail.

There are several modern concrete designs of seawalls that could work for Cayucos. For example, a curved design, of reinforced concrete would direct wave energy back to sea and prevent most waves from overtopping it. Constructing these modern seawalls can be expensive, as building one involves careful engineering and quality materials. The cost of constructing a seawall can run well into the millions of dollars (Linham, 2010). Also, there are maintenance costs involved if a seawall is to remain functioning at peak performance.

There are several disadvantages to seawalls. Seawalls can be undermined by wave action and fail, or the land flanking the wall may become 
naturally eroded and result in a stepped appearance of the coast or even help undermine the seawall. They can also starve the beach of sediment that would otherwise have come from the protected land, thus protecting the land while increasing beach erosion (Linham, 2010). A modern seawall could protect against landward erosion, storm surge, and sea level rise but may not be enough protection from all tsunamis. Any seawall may be no match for the 500 -year, 40 foot tsunami modeled in this study; but could confer protection against lesser, more probable tsunami events. The multi-hazard mitigation aspect of a seawall makes this a viable option for Cayucos.

4. Encouraging property owners and renters located within State-designated tsunami hazard zones to obtain coverage from the National Flood Insurance Program (NFIP).

There are no practical measures that can be used to physically protect all of the houses and businesses in the inundation area from tsunamis. Educating people about the need for, and availability of, insurance may be more effective at protecting their assets than physical measures. Directing people towards insurance, including subsidized insurance as it is available, is the right thing to do in the situation.

The PTVA method has proven useful in assessing vulnerability in a small coastal town, and could easily be applied to other coastal communities in the county. This study took a single researcher nine months of part time work to complete. A significant portion of this time was spent figuring out how to apply the PTVA model to Cayucos and using GIS to model inundation, update the incomplete buildings layer, and input data in 
conjunction with Google Street view. Being familiar with using the PTVA model and working full time would significantly speed the process.

This study has uncovered that the majority of buildings in the inundation area, and the majority of commercial buildings in Cayucos, are vulnerable not just to inundation, but also to complete destruction. This extreme vulnerability is a result of the low lying coast and also the fact that most buildings in Cayucos happen to be constructed in a way that makes them highly vulnerable to tsunamis. Fortunately the chance of a 500-year tsunami event occurring like the one modeled in this study is only $.2 \%$ each year. However, it is a question of when and not if a major tsunami event will affect San Luis Obispo County. Until that day comes we must strive to increase our preparedness as much as is practically possible. It is the author's hope that this study will play at least a small role in helping to protect lives and property in the future. 


\section{REFERENCES}

Barboza, T., Becerra, H., Lin, R. (September 5, 2013). Tsunami Study Finds Region at Risk. Los Angeles Times. Retrieved from http://articles.latimes.com/2013/sep/05/local/la-me- tsunami- study-20130905

California Tsunami Policy Working Group (2014). California's Tsunami Risk. Retrieved from http://www.wsspc.org/california-tsunami-policy-working-group-report/

Curtis, George. Tsunami Mitigation in Hawai'i. Science of Tsunami Hazards, 27.4 (2008): $36-42$.

Dall'Osso, F. , Gonella, M. , Gabbianelli, G. , Withycombe, G. , \& Dominey-Howes, D. (2009). A revised(ptva) model for assessing the vulnerability of buildings to tsunami damage. Natural Hazards and Earth System Sciences, 9(5), 1557-1565.

Dominey-Howes, D., Dunbar, P., Varner, J. , \& Papathoma-Köhle, M. (2010). Estimating probable maximum loss from a Cascadia tsunami. Natural Hazards, 53(1): 43-61.

Dominey-Howes, D., Papathoma, M. (2007). Validating a Tsunami Vulnerability Assessment Model (thePTVA Model) Using Field Data from the 2004 Indian Ocean Tsunami. Natural Hazards, 40: 113-136.

Eisner, R. (2005). Planning for tsunami: Reducing future losses through mitigation. Natural Hazards, 35(1), 155-162.

Eldridge, K (October 16, 2013). First Tsunami Proof Building to be Built in Westport. KOMO News Retrieved from http://www.komonews.com/news/local/First-tsunamiproof-building-to-be-built-in- Westport- 228107361.html

Federal Emergency Management Agency (June, 2009). Guidelines for Design of Structures for Vertical Evacuation from Tsunamis. Retrieved from http://www.fema.gov/media-library-data/20130726-1719-25045-1822/fema p646a.pdf

Jervey, B., (October 26, 2013). Year After Sandy, Rebuilding for Storms and Rising Seas. National Geographic Retrieved from http://news.nationalgeographic.com/ news/2013/10/131026-hurricane-sandy-anniversary-sea-level-rise-adaptation/

Linham, M., Nicholis, R. (2010). Seawalls. ClimateTechWiki. Retrieved from http://www.climatetechwiki.org/content/seawalls

Miller, K. Wilson, R. (2014) Tsunami Emergency response Playbooks and FASTER Tsunami Height Calculations: Background Information and Guidance for Use. California Geologic Survey Special Report 235. California Dept. of Conservation. Retrieved from ftp://ftp.consrv.ca.gov/ pub/ dmg/ pubs/ sr/ sr 236/ CGS Special Report 236.pdf 
National Geophysical Data Center / (NGDC/WDS) Global Historical Tsunami Database, Retrieved from http://www.ngdc.noaa.gov/hazard/tsu db.s.html

National Weather Service, NOAA. (N/D) TsunamiReady® Guidelines retrieved from http://www.tsunamiready.noaa.gov/guidelines.htm\#g2

Padilla, D (March 11, 2012) Crescent City Still Rebuilding After Devastating Tsunami. CBS News. Retrieved from http://sanfrancisco.cbslocal.com/2012/03/11/

San Luis Obispo County, Office of Emergency Services (2014). Emergency Operations Response Plan retrieved from http://www.slocounty.ca.gov/Assets/OES/Plans /Emergency+Operations+Plan+Part+1.pdf

San Luis Obispo County, Office of Emergency Services (2011). Tsunami Emergency Response Plan. Retrieved from http://www.slocounty.ca.gov/OES/plans.htm

San Luis Obispo County. (2013). Local Hazard Mitigation Plan. Retrieved from http://www.slocounty.ca.gov/OES/plans.htm

San Luis Obispo County Fire Department (2011). Northern Cayucos Tsunami Planning Map.Retrieved from http://www.calfireslo.org/PreAttack.html\#TSUNAMI PLANNING

State of California Office of Emergency Services. (2013) California Multi-Hazard Mitigation Plan.Retrieved from http://hazardmitigation.calema.ca.gov/docs/ SHMP Final 2013.pdf

State of California, Cal Fire 2014. Retrieved from http://fire-departments.org/fireDepartment/Cayucos-fire-department-california.html

State of California, California Geological Survey. (2015). Evaluation and Application of Probabilistic Tsunami Hazard Analysis in California: Phase 1: Work Group Review of Methods, Source Characterization, and Applications of the Crescent City Demonstration Project Results. California Geological Survey Report 237 retrieved from http://www.activetectonics.coas.oregonstate.edu/paper files/reports/012615 CGS\%20Special\%20Report\%20237 Evaluation\%20of\%20Probabilistic\%20Tsunami\% 20Hazard\%20Analysis\%20in\%20California-final.pdf

U.S. Census Bureau; 2013 Cayucos CDP California: ACS Demographic and Housing Estimates. Retrieved from http://factfinder.census.gov/faces/tableservices/jsf/pages/ productview.xhtml?src=CF

U.S. Census Bureau; 2010 Cayucos CDP California: Household and Families 2010 Censes Summary File 1. Retrieved from http://factfinder.census.gov/faces/ tableservices/jsf/pages/productview.xhtml?src=CF

Wiebe, D. , \& Cox, D. (2014). Application of fragility curves to estimate building damage and economic loss at a community scale: A case study of seaside, Oregon. Natural Hazards,71(3), 2043-2061. 


\section{APPENDICES}

Appendix A. SLO Fire Department, Northern Cayucos Inundation Map

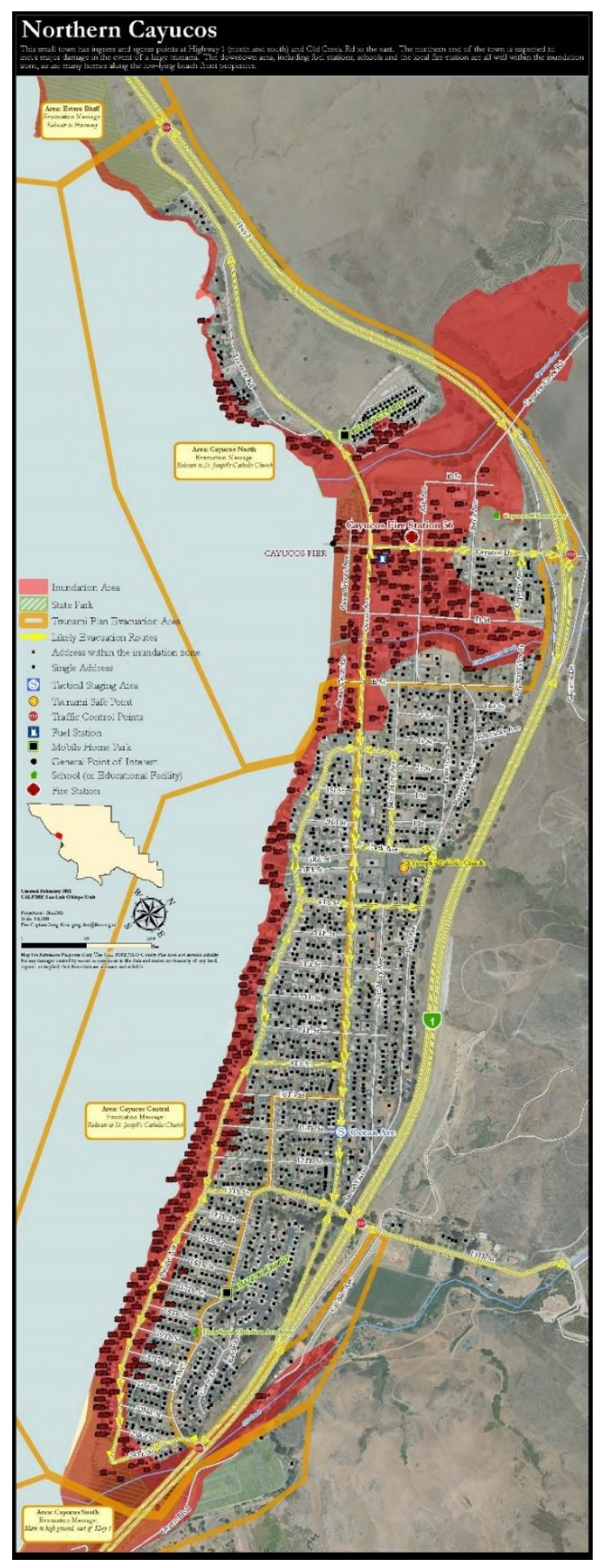


Appendix B. NWS/NOAA TsunamiReady ${ }^{\circledR}$ Guidelines

\begin{tabular}{|c|c|c|c|c|}
\hline \multirow[t]{2}{*}{ Guidelines } & \multicolumn{4}{|c|}{ Population } \\
\hline & $\begin{array}{l}< \\
2,500\end{array}$ & $\begin{array}{l}2,500- \\
14,999\end{array}$ & $\begin{array}{l}15,000- \\
40,000\end{array}$ & $>40,000$ \\
\hline \multicolumn{5}{|l|}{ Guideline 1: Communications and Coordination } \\
\hline Established 24-hour Warning Point (WP) & $\mathbf{X}^{*}$ & $\mathbf{X}^{*}$ & $\mathbf{X}$ & $\mathbf{X}$ \\
\hline Established Emergency Operations Center (EOC) & $\mathbf{X}^{*}$ & $\mathbf{X}^{*}$ & $\mathbf{X}$ & $\mathbf{X}$ \\
\hline \multicolumn{5}{|l|}{ Guideline 2: Tsunami Warning Reception } \\
\hline $\begin{array}{l}\text { Number of ways for EOC/WP to receive NWS } \\
\text { tsunami messages. (If in range, one must be NWR } \\
\text { receiver with tone alert; NWR-SAME is preferred) }\end{array}$ & 3 & 4 & 4 & 4 \\
\hline \multicolumn{5}{|l|}{ Guideline 3: Local Warning Dissemination } \\
\hline $\begin{array}{l}\text { Number of ways EOC/WP can disseminate warnings } \\
\text { to public }\end{array}$ & 1 & 2 & 3 & 4 \\
\hline NWR - SAME receivers in public facilities & $\mathbf{X}$ & $\mathbf{X}$ & $\mathbf{X}$ & $\mathbf{X}$ \\
\hline $\begin{array}{l}\text { For county/borough warning points, county/borough } \\
\text { communication network that ensures information } \\
\text { flow among communities }\end{array}$ & $\mathbf{X}$ & $\mathbf{X}$ & $\mathbf{X}$ & $\mathbf{X}$ \\
\hline \multicolumn{5}{|l|}{ Guideline 4: Community Preparedness } \\
\hline Number of annual tsunami awareness programs & 1 & 2 & 3 & 4 \\
\hline Designate/establish tsunami shelter/area in safe zone & $\mathbf{X}$ & $\mathbf{X}$ & $\mathbf{X}$ & $\mathbf{X}$ \\
\hline $\begin{array}{l}\text { Designate tsunami evacuation areas and evacuation } \\
\text { routes, and install evacuation route signs }\end{array}$ & $\mathbf{X}$ & $\mathbf{X}$ & $\mathbf{X}$ & $\mathbf{X}$ \\
\hline $\begin{array}{l}\text { Provide written, locally specific, tsunami hazard } \\
\text { response material to public }\end{array}$ & $\mathbf{X}$ & $\mathbf{X}$ & $\mathbf{X}$ & $\mathbf{X}$ \\
\hline $\begin{array}{l}\text { Schools: Encourage tsunami hazard curriculum, } \\
\text { practice evacuations (if in hazard zone), and provide } \\
\text { safety material to staff and students. }\end{array}$ & $\mathbf{X}$ & $\mathbf{X}$ & $\mathbf{X}$ & $\mathbf{X}$ \\
\hline \multicolumn{5}{|l|}{ Guideline 5: Administrative } \\
\hline Formal tsunami hazard operations plan & $\mathbf{X}$ & $\mathbf{X}$ & $\mathbf{X}$ & $\mathbf{X}$ \\
\hline $\begin{array}{l}\text { Biennial meeting between emergency manager and } \\
\text { NWS }\end{array}$ & $\mathbf{X}$ & $\mathbf{X}$ & $\mathbf{X}$ & $\mathbf{X}$ \\
\hline $\begin{array}{l}\text { Visit by NWS official to community at least every } \\
\text { other year }\end{array}$ & $\mathbf{X}$ & $\mathbf{X}$ & $\mathbf{X}$ & $\mathbf{X}$ \\
\hline
\end{tabular}


Appendix C. Map of Cayucos

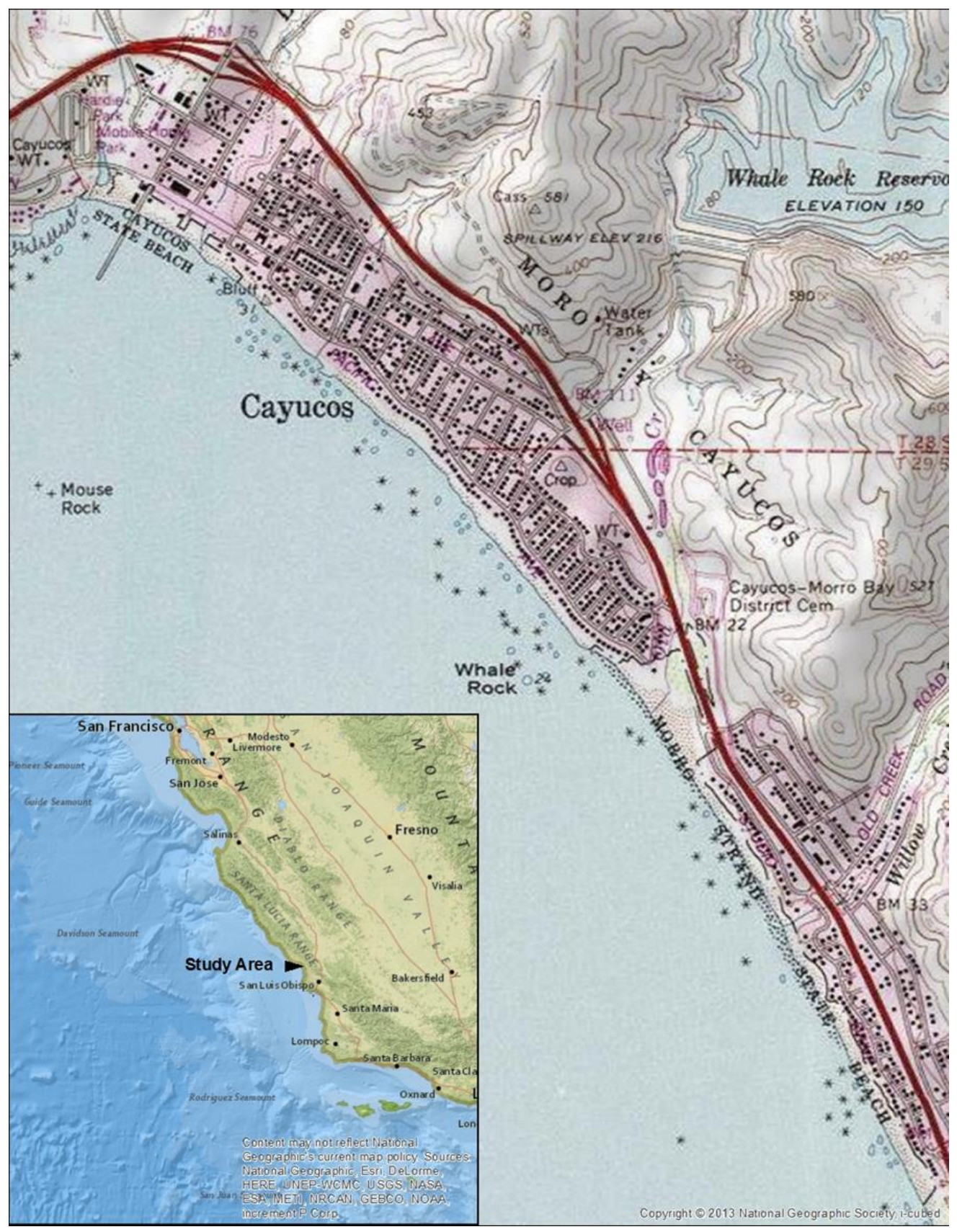




\section{Appendix D. Field Data Sheet}

APN \#

Water depth

$\begin{array}{ll}.0-1 & \mathbf{1} \\ 1-1.9 & \mathbf{2} \\ 2-2.9 & \mathbf{3} \\ 3-3.9 & \mathbf{4} \\ 4-4.9 & \mathbf{5}\end{array}$

Type: Res/Com

date:

Building Material

1. wood, wood with concrete base, steel frame with wood walls 3

2. Stone and concrete, concrete and brick 2

3. reinforced Concrete

Building row from ocean

$110 \quad 65$

$\begin{array}{llll}2 & 9 & 7 & 4\end{array}$

$\begin{array}{llll}3 & 8 & 8 & 3\end{array}$

$47 \quad 92$

$56 \quad 101$

Building orientation

3. cubic/Walls parallel to shore

4. Corners of building facing the shore line 2

3. Irregular shape (circular, hexagon ect) 1

Number of Floors

1. one story 2

2. two or more 1

Land Cover

1. None

2. Bushes and low trees 2

3. Large trees

1

Building Surroundings

1. None

2. Low earthen embankment 3

3. Low/narrow/concrete wall 2

4. high concrete wall $\quad 1$

Natural environment

1. Narrow intertidal zone $\quad 3$

2. Intermediate intertidal zone $\mathbf{2}$

3. Wide intertidal zone

Condition of building

1. Poor, abandoned

2. Fair

3. Excellent 